\title{
Introduction: Love and Desire in Education
}

\section{DAVID ALDRIDGE and DAVID LEWIN}

Why is love thrown to the wind, why is it refused an erotic rationality ... ? The answer is not hidden far away: because love is defined as a passion, and therefore as a derivative modality, indeed as optional to the 'subject', who is defined by exercise of their rationality exclusively appropriate to objects and to beings (Marion, 2008, p. 8).

If Marion is right that modern philosophy has dismissed love, the implications for education are profound. The tensions around educational eros make the claim that education might be founded upon the erotic phenomenon nearly unspeakable, and often unthinkable. This Special Issue addresses the provocative ideas of the educational recovery of the erotic phenomenon, or of love more broadly or otherwise defined.

The articles collected here bring together a range of philosophical discussions, drawing also on literary, historical, theological and psychological sources, of the ways that the erotic phenomenon presses upon modern educational theories and practices. The authors share a concern to rehabilitate love and desire to educational discourse, though with divergent ideas concerning how that could or should be achieved. Common themes include: whether it is appropriate to speak of love in educational practices and contexts, and-if it is - of what kind of love it is suitable to speak; whether the tendency to focus on the education and development of reason has led us to overlook the formation of desire; whether the influence of desire is at all possible and how such influences might be justified. Numerous authors acknowledge the risks involved in the invocation of love or desire in education, and consider the different ways to respond to those risks. An emphasis on the erotic in education-of the importance of desire, passion, feeling and touch in the educational relation - can be an important counter to a prevailing over-emphasis of education's cognitive components. Yet some educational theorists have preferred to define educational love in terms of agape, minimising the role of eros on account of its needy, instrumental, particular and even sexual connotations. Others have preferred not to speak of love at all, instead emphasising 'care' or education's 'relationality'.

A second common theme concerns love's proper object in the educational relation. How do ideas of love between teacher and student, love for subject, and love for world, interact in educational theorising? Is it more appropriate to speak of love in one context rather than others, or are different kinds of love entailed in each case? This leads to a third common theme that the articles address: whether there is a distinctively pedagogical form of love (or, related to this, whether there is in fact something intrinsically pedagogical about love).

The relevance of this collection is for us its possible contribution to the discussion around the narrowing of desired educational outcomes and an emphasis on teachers' 'professionalism'. Children learn how to think and what to know, but do they learn how to love or what to desire? Does desire need to be educated, or love 
learnt - and how could such transformations be conceived as educational outcomes? Love and desire appear as spontaneous and effervescent affirmations of the world in infancy. Yet the idea of the formation of desire signals a clear link with education, suggesting that a primal libidinal energy of human desire is not simply given, but plastic. While most parents would acknowledge some role in the rearrangement of desire, what really is at stake when we want our children to want more, or to want differently? These are dangerous ideas, since they suggest that desire itself can be altered, either through implicit socialisation, the reorientation of natural energies, benign education or more intrusive forms of behaviour modification. Is there really a difference between intrusive modification, and natural reorientation? Do such ideas entail the breaking-in of the subject, the crushing of the human spirit, or perhaps, as Gayatri Spivak characterised a human education, the 'uncoercive rearrangement of desire' (Spivak, 2012, p. 373)? And if family and friends have some role in this kind of Bildung, what role does the state have? Do states have a right or responsibility to articulate what ought to be loved?

In the context of neo-liberalism, the question of what and how to love or to desire becomes an urgent educational question as children's desire is supressed, manipulated or commodified as a form of capital. Structured by professionalising forces, the simplicity of desire to guide action and formation is obscured. For the teacher, an emphasis on professionalism might preclude a consideration of the teacher's status as exemplary amateur, ${ }^{1}$ the one who acts from love and whose love is not (yet) structured by professional expectations. Whether this is love for the student, or for the 'world' through the subject matter at hand is a complex question. But, in the end, these loves may turn out not to be so different. For, as Hannah Arendt suggests in the closing remarks of her essay 'The Crisis in Education', education requires that we love the world and children, and that the love for one may require love for the other:

Education is the point at which we decide whether we love the world enough to assume responsibility for it and by the same token save it from that ruin which, except for renewal, except for the coming of the new and young, would be inevitable. And education, too, is where we decide whether we love our children enough not to expel them from our world and leave them to their own devices, nor to strike from their hands their chance of undertaking something new, something unforeseen by us, but to prepare them in advance for the task of renewing a common world (Arendt, 1961, p. 196).

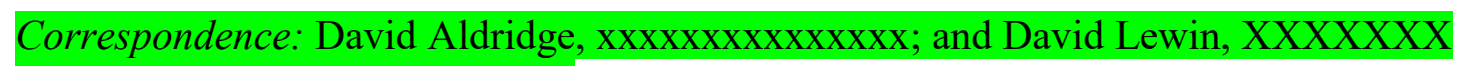

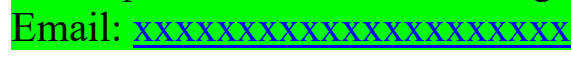

David Aldridge, Brunel University

Gaskell Building

Kingston Lane

Uxbridge

Middlesex UB8 3PH

david.aldridge@,brunel.ac.uk

David Lewin, University of Strathclyde

Lord Hope Building 
University of Strathclyde

141 St James Road

Glasgow G4 0LT

david.lewin@strath.ac.uk

\section{NOTES}

1. The Online Etymology Dictionary provides an explicit link between the amateur and the lover: "'one who has a taste for some art, study, or pursuit, but does not practice it', from French amateur 'one who loves, lover' (16c., restored from Old French ameour), from Latin amator 'lover, friend,' see https://www.etymonline.com/

\section{REFERENCES}

Arendt, H. (1961) Between Past and Future (New York, Viking Press).

Marion, J-L. (2008) The Erotic Phenomenon (Chicago, IL, University of Chicago Press).

Spivak, G. (2012) Terror: A Speech after 9/11, in: An Aesthetic Education in the Era of Globalization (Cambridge, MA, Harvard University Press), pp. 373-396. 